\title{
EXISTENCE RESULTS FOR A SYSTEM OF NONLINEAR INTEGRAL EQUATIONS IN BANACH ALGEBRAS UNDER WEAK TOPOLOGY
}

\author{
AREF JERIBI*, NAJIB KADDACHI** AND BILEL KRICHEN*** \\ *Department of Mathematics, University of Sfax \\ Faculty of Sciences of Sfax, Soukra Road Km 3.5 B.P. 1171, 3000, Sfax, Tunisia \\ E-mail: Aref.Jeribi@fss.rnu.tn \\ ** University of Kairouan, Faculty of Science and Technology of Sidi Bouzid \\ Agricultural University City Campus - 9100, Sidi Bouzid, Tunisia \\ E-mail: najibkadachi@gmail.com \\ *** Department of Mathematics, University of Sfax, Preparatory Engineering Institute \\ Menzel Chaker Road Km 0,5, BP 1172, 3018, Sfax, Tunisia \\ E-mail: krichen_bilel@yahoo.fr
}

\begin{abstract}
This paper is devoted to the study of a coupled system of nonlinear functional integral equations in suitable Banach algebras. This system is reduced to a fixed point problem for a $2 \times 2$ block operator matrix with nonlinear inputs. Hence, certain assumptions on its entries are given under a weak topology setting. These assumptions involve in particular the De Blasi measure of weak noncompactness in order to ensure the existence of solutions.
\end{abstract}

Key Words and Phrases: integral equation, Banach algebra, weakly sequentially continuous, measure of weak noncompactness, fixed point theory.

2010 Mathematics Subject Classification: 47H10, 45G15.

\section{REFERENCES}

[1] J. Appell, E. De Pascale, Some parameters associated with the Hausdorff measure of noncompactness in spaces of measurable functions, Boll. Un. Mat. Ital. B (6), 3(1984), no. 2, 497-515. (in Italian)

[2] O. Arino, S. Gautier, J.-P. Penot, A fixed point theorem for sequentially continuous mappings with application to ordinary differential equations, Funkcial. Ekvac., 27(1984), no. 3, 273-279.

[3] J. Banas, M. Lecko, Fixed points of the product of operators in Banach algebras, Panamer. Math. J., 12(2002), no. 2, 101-109.

[4] J. Banas, L. Olszowy, On a class of measures of non-compactness in Banach algebras and their application to nonlinear integral equations, Z. Anal. Anwend., 28(2009), no. 4, 475-498.

[5] J. Banas, J. Rivero, On measures of weak noncompactness, Ann. Mat. Pura Appl., 151(1988), no. $1,213-224$.

[6] A. Ben Amar, S. Chouayekh, A. Jeribi, New fixed point theorems in Banach algebras under weak topology features and applications to nonlinear integral equations, J. Funct. Anal., 259(2010), no. 9, 2215-2237.

[7] A. Ben Amar, S. Chouayekh, A. Jeribi, Fixed point theory in a new class of Banach algebras and application, Afr. Mat. 24(2013), no. 4, 705-724. 
[8] A. Ben Amar, S. Chouayekh, A. Jeribi, Fixed point results in Banach algebras for weakly convex-power condensing operators and applications, Preprint.

[9] A. Ben Amar, A. Jeribi, B. Krichen, Fixed point theorems for block operator matrix and an application to a structured problem under boundary conditions of Rotenberg's model type, Math. Slovaca, 64(2014), no. 1, 155-174.

[10] A. Ben Amar, A. Jeribi, M. Mnif, Some fixed point theorems and application to biological model, Numer. Funct. Anal. Optim., 29(2008), no. 1-2, 1-23.

[11] A. Ben Amar, M. Mnif, Leray-Schauder alternatives for weakly sequentially continuous mappings and application to transport equation, Math. Methods Appl. Sci., 33(2010), no. 1, 80-90.

[12] D.W. Boyd, J.S.W. Wong, On nonlinear contractions, Proc. Amer. Math. Soc., 20(1969), 458464.

[13] H. Brezis, Analyse fonctionnelle. Théorie et applications, Masson, Paris, 1983.

[14] T.A. Burton, A fixed-point theorem of Krasnoselskii, Appl. Math. Lett., 11(1998), no. 1, 85-88.

[15] F.E. Browder, Nonlinear operators and nonlinear equations of evolution in Banach spaces, Nonlinear Functional Analysis (Proc. Sympos. Pure Math., Vol. XVIII, Part 2, Chicago, Ill., 1968). Amer. Math. Soc., Providence, R.I., 1976, 1-308.

[16] J. Caballero, B. Lopez, K. Sadarangani, Existence of nondecreasing and continuous solutions of an integral equation with linear modification of the argument, Acta Math. Sin. (Engl. Ser.), 23(2007), 1719-1728.

[17] J.B. Conway, A Course in Functional Analysis, Springer-Verlag, Berlin 1990.

[18] F.S. De Blasi, On a property of the unit sphere in a Banach space, Bull. Math. Soc. Sci. Math. R.S. Roumanie (N.S.), 21(69)(1977), no. 3-4, 259-262.

[19] B.C. Dhage, On a fixed point theorem in Banach algebras with applications, Appl. Math. Lett., 18(2005), no. 3, 273-280.

[20] B.C. Dhage, On some nonlinear alternatives of Leray-Schauder type and functional integral equations, Arch. Math., Brno, 42(2006), no. 1, 11-23.

[21] B.C. Dhage, D. O'Regan, A fixed point theorem in Banach algebras with applications to functional integral equations, Funct. Differ. Equ., 7(2000), no. 3-4, 259-267.

[22] I. Dobrakov, On representation of linear operators on $C_{0}(T, X)$, Czechoslovak Math. J., 21(96)(1971), 13-30.

[23] A. Granas, R.B. Guenther, J.W. Lee, Some general existence principles in the Carathéodory theory of nonlinear differential systems, J. Math. Pures Appl., 70(1991), no. 2, 153-196.

[24] A. Jeribi, B. Krichen, Nonlinear Functional Analysis in Banach Spaces and Banach Algebras: Fixed Point Theory Under Weak Topology for Nonlinear Operators and Block Operator Matrices with Applications, (Monographs and Research Notes in Mathematics Series), CRC Press/ Taylor and Francis, 2015.

[25] A. Jeribi, B. Krichen, B. Mefteh, Existence solutions of a two-dimensional boundary value problem for a system of nonlinear equations arising in growing cell populations, J. Biological Dynamics, 7 (2013), no. 1, 218-232.

[26] A. Jeribi, B. Krichen, B. Mefteh, Existence of solutions of a nonlinear Hammerstein integral equation, Numer. Funct. Anal. Optim., 35(2014), no. 10, 1328-1339.

[27] N. Kaddachi, A. Jeribi, B. Krichen, Fixed Point Theorems of Block Operator Matrices On Banach Algebras and an Application to Functional Integral Equations, Math. Methods Appl. Sci., 36(2013), no. 6, 659-673.

[28] R.W. Legget, On certain nonlinear integral equations, J. Math. Anal. Appl., 57(1977), no. 2, 462-468.

[29] Y. Liu, Z. Li, Schaefer type theorem and periodic solutions of evolution equations, J. Math. Anal. Appl., 316(2006), no. 1, 237-255.

[30] A. Majorana, S.A. Marano, Continuous solutions of a nonlinear integral equation on an unbounded domain, J. Integral Eq. Appl., 6(1994), no. 1, 119-128.

[31] D. O'Regan, M.A. Taoudi, Fixed point theorems for the sum of two weakly sequentially continuous mappings, Nonlinear Anal., 73(2010), no. 2, 283-289.

[32] I. Vrabie, $C_{0}$-Semigroups and Applications, Elsevier, New-york, 2003.

[33] D.R. Smart, Fixed Point Theorems, Cambridge University Press, Cambridge, 1980. 
[34] T. Xiang, R. Yuan, A class of expansive-type Krasnosel'skii fixed point theorems, Nonlinear Anal., 71(2009), no. 7, 3229-3239.

Received: July 24, 2014; Accepted: April 23, 2015. 
